\title{
OPTIMISING POSSUM CONTROL USING ENCAPSULATED CYANIDE (FERATOX®)
}

\author{
M.D. THOMAS ${ }^{1}$, F.W. MADDIGAN ${ }^{1}$, J.A. BROWN ${ }^{2}$ and M.TROTTER ${ }^{3}$
}

\author{
${ }^{1}$ Pest Control Research Ltd, P.O. Box 7223, Christchurch, New Zealand \\ ${ }^{2}$ Department of Mathematics and Statistics, University of Canterbury, Private \\ Bag 4800, Christchurch, New Zealand \\ ${ }^{3}$ Otago Regional Council, Private Bag, Balclutha, New Zealand \\ Corresponding author: malcolm.thomas@pcr.co.nz
}

\begin{abstract}
Feratox ${ }^{\circledR}$ is an encapsulated cyanide product used extensively throughout New Zealand for possum control. It has advantages of being lightweight and is not legally required to be checked daily, as are leg-hold traps. This study evaluated delivery methods for Feratox ${ }^{\circledR}$ by comparing the number of possums killed by Feratox ${ }^{\circledR}$ treatments with the number of possums killed by an industry accepted standard, i.e. possum captures in leg-hold traps. When Feratox ${ }^{\circledR}$ was used in plastic bags coated with a rat repellent and fixed to wires located at $5 \mathrm{~m}$ spacings, significantly less possums were killed than in traps. However, when applied in bait stations at $50 \mathrm{~m}$ intervals, Feratox ${ }^{\circledR}$ killed as many possums as traps, especially when possums were prefed non-toxic bait. Feratox ${ }^{\circledR}$ was also as effective as traps when used in paper bags located on trees $20 \mathrm{~m}$ apart and used with a flour and icing sugar blaze. This study suggests that Feratox ${ }^{\circledR}$ can provide a more cost-effective alternative to trapping in areas with low to medium possum densities.
\end{abstract}

Keywords: possums, trapping, poisoning, cyanide, vertebrate pest control.

\section{INTRODUCTION}

Poisonous cyanide bait is commonly used to control possums (Trichosurus vulpecula) because it kills quickly and has few undesirable effects from an animal welfare perspective (Gregory et al. 1998). Furthermore, possums can be safely recovered for skinning, autopsy or counting. Initially cyanide was available only in a paste form, but such baits have disadvantages. Native birds are particularly at risk of ingesting the cyanide paste (Spurr 2000) and it emits hydrogen cyanide (HCN) gas, which is a hazard to the user and may reduce the palatability of the paste to possums (Warburton \& Drew 1994). This can result in sub-lethal poisoning, which may cause bait shyness and make the possums more difficult to kill in subsequent control operations (Henderson et al. 1997; Morgan et al. 2001).

To overcome these problems an encapsulated form of cyanide called Feratox ${ }^{\circledR}$ was developed and registered in 1995. Feratox ${ }^{\circledR}$ consists of a $6 \mathrm{~mm}$ wide compressed pellet of $>90 \%$ potassium cyanide that is coated with a hard material to prevent the emission of HCN gas. Since its introduction, Feratox ${ }^{\circledR}$ has become the industry-accepted method for cyanide baiting and more than six million Feratox ${ }^{\circledR}$ pellets are sold annually in New Zealand (J. Kerr, pers. comm.). Feratox ${ }^{\circledR}$ is typically used in combination with a specially formulated feed paste called Ferafeed $®$ that is attractive to possums (Morgan \& Rhodes 2000). The Feratox $®$ pellets are embedded in the Ferafeed $₫$ and then fed to the possums using a variety of bait delivery devices. The two most commonly used devices are plastic bait feeders or bait stations (Thomas 1994) and small bait bags. The aim of this study was to compare four Feratox ${ }^{\circledR}$ presentation methods using bait bags and bait stations. 


\section{METHODS}

Field trials compared four Feratox ${ }^{\circledR}$ presentation methods: (i) plastic bait bags on wires, (ii) paper bags stapled to trees, (iii) bait stations with prefeeding and (iv) bait stations without prefeeding (Table 1). Four sites throughout New Zealand were used to evaluate the methods, but not all methods were tested at all sites. For each method, the devices were placed along $200 \mathrm{~m}$ long lines that were spaced at least $200 \mathrm{~m}$ apart so that possum kills on each line were unlikely to influence kills on adjacent lines (NPCA 2002). Both trapping and baiting were conducted on three consecutive fine nights at all study sites. At each site, the Feratox lines were paired with accompanying leg-hold trap lines laid out according to a standard protocol used throughout New Zealand to monitor possum numbers (NPCA 2002). Briefly this involves locating 10 leg-hold traps spaced at $20 \mathrm{~m}$ intervals along $200 \mathrm{~m}$ long lines. The traps are attached to trees and a flour and icing sugar "blaze" is used on the trees to attract possums to the trap. Leg-hold traps are considered to be an effective method to control possums (Warburton 1992), so Feratox ${ }^{\circledR}$ presentation methods that matched or exceeded possum kills gained from trapping were considered to be effective.

Plastic bags ( $75 \times 100 \mathrm{~mm}$ ) were used in pine plantations near Kaitaia, Northland, in July 2000, and at Kaiangaroa Forest, Bay of Plenty, in February 2001. The bags were placed on wires at $5 \mathrm{~m}$ spacings along 20 lines ( 800 bags) at each site (Table 1). Wires were used to help deter rats, which also eat or remove the Feratox ${ }^{\circledR}$ pellets (McGlinchy $\&$ Warburton 2000). In addition, the bags were coated with a white paste containing a rat repellent (Morgan \& Rhodes 2000). Each bag contained $20 \mathrm{~g}$ of Ferafeed ${ }^{\circledR}$ and one Feratox ${ }^{\circledR}$ pellet.

Paper bags (76 x $146 \mathrm{~mm}$ ) containing $20 \mathrm{~g}$ of Ferafeed ${ }^{\circledR}$ and three Feratox ${ }^{\circledR}$ pellets were stapled to trees at $20 \mathrm{~m}$ intervals on 20 lines in podocarp/beech forest in the Catlins Forest, Otago, in January 2001, and on 10 lines near Rahu Saddle, North Canterbury, in April 2002 (Table 1). Beside each bag, a blaze of a 5:1 flour and icing sugar mixture was made on the tree from ground level to about $50 \mathrm{~cm}$ high using the same method specified for leg-hold trapping (NPCA 2002).

Bait stations containing $200 \mathrm{~g}$ of Ferafeed ${ }^{\circledR}$ and six pellets of Feratox ${ }^{\circledR}$ were located in beech (Nothofagus sp.) forest near Rahu Saddle, North Canterbury, in April 2002. The stations were placed at $50 \mathrm{~m}$ intervals along 20 lines (i.e. a total of 200 stations with 5 stations per line; Table 1). Ten of the lines were prefed (Thomas et al. 1996) with $200 \mathrm{~g}$ of Ferafeed ${ }^{\circledR}$ that did not contain Feratox ${ }^{\circledR}$. This prefeed was available to possums for six days and then stations were refilled with $200 \mathrm{~g}$ of Ferafeed ${ }^{\circledR}$ containing six pellets of Feratox®.

The numbers of Feratox ${ }^{\circledR}$ pellets used per presentation device were chosen to ensure a potential kill of 30 to 40 possums per line, i.e. 40,30 and 30 Feratox ${ }^{\circledR}$ pellets per line for the plastic bags, paper bags and bait stations respectively.

\section{Statistical analysis}

Mean kills per line obtained from each Feratox ${ }^{\circledR}$ presentation method were compared to mean kills per line obtained from the accompanying trap lines using t-tests. Data were log transformed to stabilise the variances and differences were considered significant at $\mathrm{P}<0.05$.

\section{TABLE 1: The experimental design for each treatment at each field site.}

\begin{tabular}{lrccccc}
\hline Treatment & Site & Lines & $\begin{array}{c}\text { Devices } \\
\text { /line }\end{array}$ & $\begin{array}{c}\text { Spacing } \\
(\mathrm{m})\end{array}$ & $\begin{array}{c}\text { Feratox } \\
\text { capsules/device }\end{array}$ & $\begin{array}{c}\text { Flour } \\
\text { blaze }\end{array}$ \\
\hline 1. Plastic bags & Northland & 20 & 40 & 5 & 1 & No \\
2. Plastic bags & Kaiangarora & 20 & 40 & 5 & 1 & No \\
3. Paper bags & Catlins & 20 & 10 & 20 & 3 & Yes \\
4. Paper bags & Rahu & 10 & 10 & 20 & 3 & Yes \\
5. Bait stations (prefed) & Rahu & 10 & 5 & 50 & 6 & No \\
6. Bait stations (not prefed) & Rahu & 10 & 5 & 50 & 6 & No \\
\hline
\end{tabular}




\section{RESULTS AND DISCUSSION}

Feratox ${ }^{\circledR}$ in plastic bags on wires killed significantly fewer possums than traps (Northland $24 \%$ of total trap kills, $\mathrm{P}<0.05$; Kaiangaroa $36 \%$ of total trap kills, $\mathrm{P}<0.05$; Fig. 1). When paper bags were attached to trees and accompanied with a flour blaze, similar possum kills were achieved to trapping (Catlins Forest $53 \%$ of total trap kills, $\mathrm{P}=0.25$; Rahu Saddle $58 \%$ of total trap kills, $\mathrm{P}=0.27$; Fig. 1). Bait stations also achieved similar possum kills to trapping (prefed $48 \%$ of total trap kills, $\mathrm{P}=0.33$; not prefed $37 \%$ of total trap kills, $\mathrm{P}=0.34$; Fig. 1). There was no significant difference in possum kills achieved with and without prefeeding when using bait stations $(\mathrm{P}=0.66)$. However, the higher kill achieved with prefeeding supports results from previous studies which indicate that higher kills can be achieved if possums are prefed when bait stations are used (Thomas 1994; Thomas et al. 1996). The reduced kills achieved when using plastic bags may have been due to the following differences compared to the paper bag method. Firstly, the plastic bags were coated with a rat repellent paste that may have deterred possums. Secondly, the plastic bags were on wires and not on trees with a flour blaze and this may have made them less visible to the possums. A previous study has shown that significantly more possums are caught in traps when a flour blaze is used (Warburton \& Yockney 2000). Thirdly, it is possible that possums had more difficulty ripping open the plastic bags and finding the Feratox ${ }^{\circledR}$ than the paper bags.

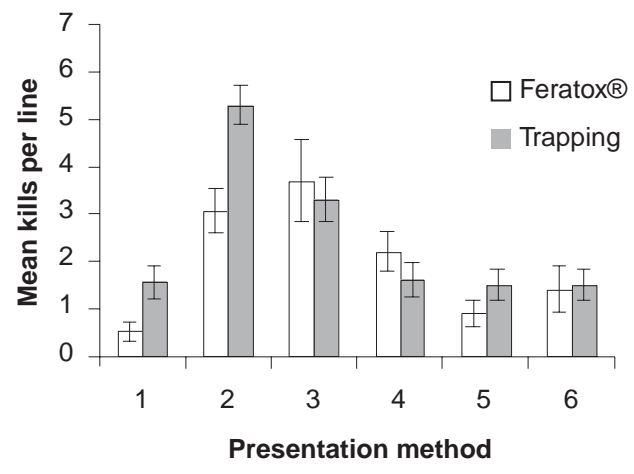

FIGURE 1: Mean possum kills $( \pm$ SEM) per line when using different methods of presenting Feratox ${ }^{\circledR}$ compared with a "control" method using leghold traps. Trapping and baiting were undertaken on three consecutive fine nights. Presentation methods were $1 \& 2=$ plastic bags on wires, $3 \& 4$ = paper bags stapled to trees with flour blaze, 5 = bait stations without prefeeding and $6=$ bait stations with prefeeding.

\section{CONCLUSIONS}

The results presented in this paper show that Feratox ${ }^{\circledR}$ in bait stations and paper bags can be as effective as leg-hold trapping for possum control in New Zealand. Also the method is more cost-effective than traps because trappers are legally required to check traps daily (Animal Welfare Act, 1999) which increases costs. Traps are also heavy compared to bait bags and bait stations and this restricts the numbers that can be carried. However, despite the advantages of Feratox®, possum control contractors need to be aware that possum kills can be reduced by rats eating or removing the Feratox ${ }^{\circledR}$ capsules. Research to investigate methods to prevent rat interference, such as rat proof bait stations and rat repellents in baits, could help overcome this problem. 


\section{ACKNOWLEDGEMENTS}

We would like to thank the Department of Conservation for funding the majority of this study. Some funding was also provided by Northland Regional Council, Connovation Ltd, Epro Ltd and Trappers NZ Ltd. We would also like to thank Carl Cooper (Northland Regional Council), Kevin Nicholas (Epro Ltd), Graham and Trish Higginson (Trappers NZ Ltd) and Phillip Commins for logistical support and help with the selection of study sites. Jeremy Kerr (Feral IP Ltd) kindly provided the bait materials used in the study and Laura Sessions provided editorial assistance.

\section{REFERENCES}

Gregory, N.G.; Milne, L.M.; Rhodes, A.T.; Littin, K.E.; Wickstrom, M.; Eason, C.T. 1998: Effect of potassium cyanide on behaviour and time to death in possums. N.Z Vet. J. 46(2): 60-64.

Henderson, R.J.; Morriss, G.A.; Morgan, D.R. 1997: The use of different types of toxic bait for sustained control of possums. Proc. 50th N.Z. Plant Prot. Conf.: 382-390.

McGlinchy, A.; Warburton, B. 2000: Review of the potential of wax-blocks and Feratox ${ }^{\circledR}$ cyanide pellets as an alternative to traps for monitoring possum populations. Landcare Research Contract Report LC9899/93. Landcare Research, Lincoln, New Zealand. $12 \mathrm{p}$.

Morgan, D.R.; Rhodes, A.T. 2000: Selectivity of Ferafeed ${ }^{\circledR}$ paste bait treated with a rodent repellent - a cage trial. N.Z. Plant Prot. 53: 316-320.

Morgan, D.R.; Milne, L.; O'Conner, C.; Ruscoe, W.A. 2001: Bait shyness in possums induced by sublethal doses of cyanide paste. Int. J. Pest Mgt 47(4): 227-284.

NPCA. 2002: Protocol for possum population monitoring using the trap-catch method. National Possum Control Agencies, Wellington, New Zealand.

Spurr, E.2000: Impacts of possum control on non-target species. In: Montague, T.L. ed. The brushtail possum : the Biology, Impact and Management of An Introduced Marsupial. Manaaki Whenua Press, Lincoln, New Zealand. Pp. 175-186.

Thomas, M.D. 1994: Possum control in native forests using sodium monofluoroacetate (1080) in bait stations. Proc. 47th N.Z. Plant Prot Conf: 107-111.

Thomas, M.D.; Henderson, R.J.; Hickling, G.J. 1996: Optimising the use of bait stations for possum control. In: Wright, D.E. ed. Proceedings of a workshop on improving conventional control of possums. Royal Soc. N.Z. Mis. Series 33: 65-69.

Warburton, B. 1992: Victor foot-hold traps for catching Australian brushtail possums in New Zealand: capture efficiency and injuries. Wildlife Soc. Bull. 20: 67-73.

Warburton, B.; Drew, K.W. 1994: Extent and nature of cyanide-shyness in some populations of Australian brushtail possums in New Zealand. Wildlife Res. 21: 599-605.

Warburton, B.; Yockney, I. 2000: Comparison of two luring methods for traps used to monitor possum populations in tussock country. Landcare Research Contract Report LC9900/126. Landcare Research, Lincoln, New Zealand. 9 p. 